Technological University Dublin

DƯBLIN

ARROW@TU Dublin

2018-07-19

\title{
The Positive Feedback Cycle in the Electricity Market: Residential Solar PV Adoption, Electricity Demand and Prices.
}

\author{
Michael Chesser \\ Technological University Dublin \\ Jim Hanly \\ Technological University Dublin \\ Damien Cassells \\ Technological University Dublin
}

See next page for additional authors

Follow this and additional works at: https://arrow.tudublin.ie/buschacart

Part of the Economics Commons

\section{Recommended Citation}

Chessar, M., Hanly, J., Cassells, D., Apergis, N. The Positive Feedback Cycle in the Electricity Market: Residential Solar PV Adoption, Electricity Demand and Prices. Energy Policy, 122, 36-44.

This Article is brought to you for free and open access by the School of Accounting and Finance at ARROW@TU Dublin. It has been accepted for inclusion in Articles by an authorized administrator of ARROW@TU Dublin. For more information, please contact arrow.admin@tudublin.ie, aisling.coyne@tudublin.ie, gerard.connolly@tudublin.ie. Funder: TU Dublin PhD Scholarship 
Authors

Michael Chesser, Jim Hanly, Damien Cassells, and Nicholas Apergis

This article is available at ARROW@TU Dublin: https://arrow.tudublin.ie/buschacart/46 


\title{
The Positive Feedback Cycle in the Electricity Market: Residential Solar PV Adoption, Electricity Demand and Prices.
}

\begin{abstract}
Micro renewable energy systems (MRES) such as Photovoltaic (PV) are an increasingly important element of National energy strategies. However, the success of these installations has given rise to a positive feedback cycle whereby increased customer adoption results in reduced demand from Utility providers. This leads to price increases and further incentives customers to adopt MRES. This paper investigates the existence of a positive feedback cycle by developing a theoretical model based on simultaneous equations and estimating it using the three stage least squares approach using data from the UK, Australian and Irish Markets. Results indicate strong support for the idea of a positive feedback cycle. This reinforces the need for stakeholders to consider this issue in framing future energy policies to ensure that the adoption of solar PV is supported in a sustainable way, while not punishing non-adopters with higher electricity rates.
\end{abstract}

Keywords: Residential Solar PV, Positive Feedback Cycle, Panel Data Analysis.

\section{Introduction}

Micro renewable energy systems are small scale energy systems which generate small amounts of energy when compared to traditional centralized power plants. Micro renewable energy systems have now made it possible for home owners to retrofit their premises to generate their own electricity and/or heat, thus becoming more self-sufficient. Allen, Hammond \& McManus (2008) references a study where it was predicted that electrical micro renewable energy systems could provide 30 to $40 \%$ of the United Kingdoms' electricity needs by 2050 .

Governments worldwide have included strategies to stimulate the growth of micro renewable energy systems at the residential level as part of their overall energy policy aimed at combatting climate change. Governments have used a variety of support mechanisms to achieve their targets which include Feed-in Tariffs (Fit), point of sales rebates including Renewable Energy Certificates (REC), and tax benefits. These policies have been successful in increasing the number installations particularly that of solar photovoltaic systems in the residential sector in countries like the United States of America, Australia and the United Kingdom (Allen et al., 2008; Chapman, McLellan, \& Tezuka, 2016). 
Though, the increasing popularity of residential solar photovoltaic systems in electricity markets has led some to suggest that it has created a positive feedback cycle or loop. Simply put a positive feedback cycle is a situation where, action A generates more of action B which in turn generates more of action A. In economics, a positive feedback cycle results in a systemic risk to the system (Cai, Adlakha, Low, De Martini, \& Chandy, 2013; Rodrigues et al., 2016; Sahu, 2015).

There has been a vast amount of literature on the economic impact of renewable energy systems; however, the literature has mainly been focused on renewable energy systems at a macro level (Payne, 2010; Salim, Hassan, \& Shafiei, 2014; Shafiei \& Salim, 2014). A new line of literature has begun to investigate the economic repercussions of increasing number of micro-generators, particularly that of residential solar photovoltaic (PV) systems and the effects on countries electricity markets which may result in a positive feedback cycle which could possibly lead to a utility 'death spiral'. This scenario is a result of residential electricity customers adopting solar photovoltaic systems due to high electricity prices will therefore reduce their consumption from the electricity grid. In response to falling sales electrical utilities will have to raise their prices as the costs ${ }^{1}$ associated with the generation of electricity do not decrease in proportion to the decrease in electricity demanded. The increase in price by electrical utilities thus incentivises more of the remaining electricity customers to adopt solar photovoltaic systems. Increasing penetration levels of residential solar photovoltaic systems onto a grid could further accelerate the positive feedback cycle and could have several implications. The increasing electricity prices will be borne by low and medium income households who cannot afford solar photovoltaic system and in a worst case scenario where electricity price increases will be futile in raising sufficient revenues to cover their total costs could potentially force electrical utilities into a death spiral (Costello \& Hemphill, 2014; Felder \& Athawale, 2014).

Of the literature that empirically investigates the topic of a positive feedback cycle in the residential electricity market caused by an increasing number of solar PV, has thus far mainly focused on the American experience. Therefore, this paper will be the first to extend the ideas from the existing literature on the American experience to a newly selected group of countries, Australia, Ireland and the UK. To address this issue, this paper firstly models the positive feedback cycle caused by consumers in the residential sector by deciding to adopt solar photovoltaic systems and the resulting implications on demand and pricing in the residential

${ }^{1}$ This is because the electrical utilities have to pay for transmission and distribution infrastructure and these fixed costs are recovered over decades. 
electricity market. Following this, a three stage least squares regression is performed for the panel of countries to investigate whether a positive feedback cycle is being experienced. Our findings show support for: (1) increasing residential electricity prices leading to higher installation rates of residential solar photovoltaic, (2) residential solar photovoltaic installations lead to higher residential electricity prices, (3) residential solar photovoltaic installations negatively affect residential electricity demand.

The results attained in this paper will be used to inform and support policy makers as they consider potential changes to residential electricity rates that could affect solar photovoltaics role in advancing policy objectives and not to punish non-adopters with higher electricity rates.

The paper is organised as follows: Section 2, is the material and methods sections; provides details on the model development, the estimation technique, data specifications and a descriptive statistics subsection. In Section 3, the results of the three stage least squares regression of our simultaneous equation model are presented and discussed. Section 4 contains the concluding remarks and policy implications.

\section{Literature Review}

The earliest reference to the positive feedback cycle as a result of micro-RES the author could find was by Severance (2011), however these terms aren't used in the study. Severance notes that utility managers have an "unspoken fear" of a death spiral scenario due to "on-site power" and the collection of higher and higher rates from poorer and poorer customers. Others studies (T. Nelson, Simshauser, \& Kelley, 2011; T. Nelson, Simshauser, P., \& Nelson, J., 2012) raise concerns about the impact of favourably tariffs for micro-RES are having.

The hypothesis of a positive feedback cycle induced by residential solar PV, has motivated a new line of research into the interactions between residential solar PV adoption rates and electricity prices and demand. Arthur (1990) first wrote about the influence of the positive feedback on economic systems. In his paper, the author saw the positive feedback cycle as the driving force in determining which of competing technologies would dominate a market. He concluded that at the start, markets are unstable and small increases to a new technologies market share can expand its growth exponentially (Ruth \& Hannon, 2012).

Studies examining the impact of electricity retail rate structure on solar PV are not new, however, most of them have stopped short of investigating whether it would lead to a positive feedback cycle (Darghouth, Barbose, \& Wiser, 2011; McLaren, Davidson, Miller, \& Bird, 
2015; Mills, Wiser, Barbose, \& Golove, 2008). In a paper by Chew, Heling, Kerrigan, Jin, Tinker, Kolb, Buller \& Huang (2012) for Pacific Gas \& Electric Company, the authors acknowledge that a positive feedback cycle is in effect and conclude that electric utilities must adapt their rate-making procedures to ensure that both solar-PV adopters and non-adopters are fairly charged for their cost of service. To do this the authors presented a model that could be used by electrical utilities to estimate the impact of various policies proposals will have on cost shifts and residential rooftop solar PV systems. In Cai et al.(2013), the authors investigate how the adoption of solar PV systems by households leads to a positive feedback cycle via increasing electricity rates. They modelled solar PV adoption for a specific investor owned utility, subject to rate-of-return regulation in California. The results from their model illustrate that the feedback cycle reduces the time it takes for solar PV capacity to reach $15 \%$ of peak demand by up to 4 months and has a greater impact in later years. Costello and Hemphill (2014) investigate whether the 'death spiral' facing electrical utilities due to increases in distributed generation $^{2}$ is a reality or overstatement. The authors conclude that electrical utilities are in for some tough times ahead, but it is due to several factors not just distributed generation. Moreover, it is in the interests of policy makers to ensure electrical utilities avoid entering a death spiral as this outcome would hurt customers in the long run, since they will have to rely on the grid on occasions. A similar conclusion is presented by Laws, Epps, Peterson, Laser \& Wanjiru (2017) where they investigate how many electric utilities are changing their pricing structures to address the rapidly-growing market for residential solar PV systems. The authors note that there is little knowledge about how changes to utility pricing structures would affect the adoption rates of solar PV systems, as well as the ability of utilities to prevent widespread grid defection. Laws et al. (2017) carry out simulations on a system dynamics model to predict how changes to the retail price of electricity impact on the adoption rates of residential solar PV. A sensitivity analyses is also conducted to investigate the likelihood of a utility 'death spiral'. Their results indicate that a utility 'death spiral' requires a perfect storm of high intrinsic adoption rates, rising utility costs, and favourable customer financials. Eryilmaz and Sergici (2016), investigate the price-responsiveness of the residential customers with increasing residential solar PV penetration and projected future electricity sales to the residential sector considering various future solar PV penetration scenarios. Their results show that increasing residential electricity prices are associated with an increase in residential solar PV installations and using their findings for the estimated elasticity values, they project the share of utility

${ }^{2}$ Distributed generation refers to the generation of energy close to the place where energy issued. It can mean a range of generator sizes; from residential households to community or district-level. 
electricity sales reduction due to solar residential sector between 2013 and 2020. In a future scenario where there is a $25 \%$ residential solar PV penetration by 2020 , about $1.2 \%$ of the projected growth of the electricity sales to the residential customers will be taken over by rooftop solar PV.

The literature published on the topic of a positive feedback cycle due to residential solar PV adoption to date has focused on the American experience. This paper extends the ideas from the literature to a selected group of countries, Australia, Ireland and the UK, to investigate whether residential solar PV adoption in these countries has led to the existence of a positive feedback cycle.

\section{Material and Methods}

\subsection{Data Specifications}

We consider monthly data spanning the period from 2010 to 2015, for three countries: Australia, Ireland and the United Kingdom in this study. The three countries can be seen to represent micro-RES at three different stages of growth; infancy, intermediate and mature respectively. One reason for the different levels of penetration between the countries is government support mechanisms. A possible reason for the slow residential solar PV uptake in Ireland when compared to the other countries is weak government support mechanisms. In Ireland, the ESB networks and Electric Ireland (formally known as ESB Customer Supply) ran a 'pilot scheme' from 2009 till 2014 for micro generators of electricity. Under this 'pilot scheme', micro-generators where offered a support package of a free installation of an import/export meter and support payment of 10 cent $/ \mathrm{kWh}$ for the duration of their contract (the last of these contracts expire in 2017). For micro-generators who missed the deadline of the 'pilot scheme', Electric Ireland offered an export payment of 9 cents per $\mathrm{kWh}$; however this offer ceased to on the 31 st December 2016. There is currently no other electricity supplier in Ireland offering payment for electricity produced from microgeneration technologies (ElectricIreland, 2014).

Whereas in Australia and the UK the support mechanisms for residential solar PV are much more generous by comparison to the Irish experience. In the UK, residential solar PV systems are supported through several measures including; reduced VAT on systems, capital grants for householders and government policies, such as the Feed-in Tariff (FIT). In the first year of the FIT payment period (April 2010 to April 2011) for residential solar PV systems, the feed in 
price for systems at and below $10 \mathrm{~kW}$ ranged from 43 to 49 cents. In the following years the price has been continuously reviewed and amended every several months. The price in January 2016 ranged between 12.03 to 5.73 cents for systems at or below $10 \mathrm{~kW}$. In Australia, there is two forms of support for adopters of residential solar PV systems, firstly at the federal level there is an upfront grant to reduce the capital cost of a residential solar PV system. Secondly form of funding is a solar FIT, the price of the FIT is managed at a state and territory level. In 2010, the FIT price across the Australian states and territories ranged from 20 to 66 cents (T. Nelson et al., 2011; Zahedi, 2010).

It is important to note that the definition of micro-generation can vary from country to country, but generally refers to small-scale local energy generation. ${ }^{3}$ To the empirical ends of this study, we define residential solar PV having a max rated capacity up to $10 \mathrm{~kW}$ (BaltaOzkan, Yildirim, \& Connor, 2015; CER, 2016; Li, Boyle, \& Reynolds, 2011). The solar PV data for the UK were obtained from the statistics portal on the UK's government website. The solar PV data for Ireland were collected from ESB Networks and for Australia they were sourced from the Australian Photovoltaic Institute. For each country, the variable solar PV uptake was constructed which represents the average capacity installed per system per month and is reported as the average rated capacity (kilowatt/kW) installed per month. Data on the cost of solar PV installations are collected from Open PV Project published by the National Renewable Energy Laboratory and is reported as the average euro per $\mathrm{kW}$. The residential electricity demand variable for Ireland is obtained from the Commission of Energy Regulation (CER), the statistics portal on the UK's government website for the U.K. and the statistics portal on the website Office of the Chief Economist for Australia. The variable measurement is gigawatts hour (GWh). The Coal Share variable for Ireland is collected from the Central Statistics Office, for the UK from the UK's government website and for Australia the statistics portal on the website office of the Chief Economist. The variable is reported as the monthly percentage of coal used in electricity production (\%).. . The monthly wholesale price of electricity for Australia Energy Market Operator and for Ireland it was sourced from the Single Electricity Market Operator. The monthly UK wholesale electricity price was sourced from Thomson Reuters DataStream. The monthly wholesale price of electricity is reported in $€ / \mathrm{MWh}$. Atmospheric variables, average temperature and sunlight hours, all are sourced from Met Éireann for Ireland, the statistics portal on the UK's government website and the Met

\footnotetext{
3 In Ireland ESB Networks classify a generator as 'micro' when the electricity generating system has a maximum rated capacity of $11 \mathrm{~kW}$ while in the U.K it's any generating system with a capacity below $50 \mathrm{~kW}$. In Australia the definition for micro generators, is a solar PV system with a rated capacity of no more than $100 \mathrm{~kW}$.
} 
Office for the UK, and the Bureau of Meteorology for Australia. The Scheme variable is a dummy variable, when the Scheme variable equals 1 represents when a federal government micro-generation support scheme is in operation, 0 represents otherwise. Information to whether a scheme is in operation is sourced from each countries' department of the environment website. This study uses data at a monthly frequency, however, some of the variables are only reported on a bi-annually or annually frequency basis by their sources. A linear extrapolation ${ }^{4}$ is applied in that case to acquire monthly values. Both Appendix A and B have a table detailing each variables data source and description.

\subsection{Model Development}

The positive feedback cycle is centred on the idea that increasing electricity prices is a key variable in the decision making process for solar PV adoption. Growing adoption levels of residential solar PV systems onto the residential electricity market will decrease residential electricity demand and this in turn will lead to increasing residential electricity prices. According to Kaufmann and Vaid (2016), empirical studies (Ballester \& Furio, 2015; Gelabert, Labandeira, \& Linares, 2011; Nicholson, Rogers, \& Porter, 2010) examining the effects of renewable energy systems on electricity price have used some variants of the following equation (1) as a starting point:

$$
P_{t}=\alpha+\beta_{1} \operatorname{Load}_{t}+\beta_{2} R E_{t}+\beta_{3} N R E_{t}+\beta_{4} P F F_{t}+\beta_{5} D_{u m}+\varepsilon_{t}
$$

where $P$ is the price of electricity at time period $t, L o a d$ is the electricity load, $R E$ is the quantity of electricity from renewable sources, $N R E$ denotes electricity from traditional energy sources, $P F F$ is the price of fossil fuels, Dum are dummy variables that represents time periods (year, month, etc.) and $\varepsilon$ is the error term. Using equation (1) as a starting point, we can transform it into multiple equations, to treat simultaneously residential solar PV uptakes, residential electricity prices and residential electricity demand as endogenous ${ }^{5}$. A simultaneous equations model is used when one or more of the explanatory variables is jointly determined with the dependent variable. Given the nature of the positive feedback cycle, a simultaneous equation model would be best suited to model this relationship and to ensure the treatment of any

\footnotetext{
${ }^{4}$ We use "Ipolate" command with epolate option in Stata to conduct the linear extrapolation. We have sufficient historical data points to do the extrapolation.

${ }^{5}$ These are jointly dependent variables; or, those determined within the system of equations.
} 
endogeneity bias. The three equations that comprise our simultaneous equations model are shown below and explained in the following paragraphs:

$$
\begin{aligned}
& \operatorname{lnPV}_{t}=\propto_{0}+\propto_{1} \text { InPElec }_{t}+\propto_{2} \text { Scheme }_{t}+\propto_{3} \text { lnSunlight }_{t}+\propto_{4} \text { InAvrCostPV }_{t}+ \\
& D_{y}^{\text {year }}+D_{m}^{\text {month }}+\varepsilon_{1, t}
\end{aligned}
$$

InPElec $_{t}=\beta_{0}+\beta_{1}$ CoalShare $_{t}+\beta_{2}$ InPElec $_{t-1}+\beta_{3} \operatorname{lnPV}_{t}^{*}+\beta_{4} \operatorname{lnWPElec}_{t}+$ $D_{y}^{\text {year }}+D_{m}^{\text {month }}+\varepsilon_{2, t}$

$$
\begin{aligned}
& \ln E D_{t}=\theta_{0}+\theta_{1} \operatorname{lnPElec}_{t}^{*}+\theta_{2} \ln P V_{t}^{*}+\theta_{3} \operatorname{lnTemp} \operatorname{pe}_{t}+\theta_{4} \operatorname{lnInc_{t}}++D_{y}^{y e a r}+ \\
& D_{m}^{\text {month }}+\varepsilon_{3, t}
\end{aligned}
$$

We start our simultaneous equation model of the positive feedback cycle with the residential solar PV uptake equation (2), which represents the residential electricity consumers' decision to adopt a solar PV system. Modelling the motivation of a consumers decision to adopt solar PV has been explored in studies such as Balcombe, Rigby \& Azapagica (2013), BaltaOzkan, et al. (2015) and Zhang, Song \& Hamori (2011) where they concluded that the decision making process of solar PV is attributed to a number of factors, including environmental, financial and social interactions. The dependent variable in equation (2) is the residential solar PV uptake $(P V)$ it is a function of the residential electricity price (PElec) for an average house and it is expected that when residential electricity prices increase, the incentive for people to adopt residential solar PV also increases as solar PV becomes financially feasible. The next variable included is the average monthly sun light hours ${ }^{6}$ (Sunlight), as it is an important climatic variable in the decision making process of adopting solar PV. It's expected that areas with a higher number of sunlight hours would have a higher penetration levels of residential solar PV. The monthly average cost of solar PV (AvrCostPV) is included and it is expected that falling costs of residential solar PV systems would result in a greater number of installations. The variable government support scheme (Scheme) is a dummy variable representing whether or not there is a support scheme in place for solar PV in a given month. It's expected that when support schemes are in place, installation rates will be higher. Moreover, time dummies for both the Month and Year are included (Filippini, 2011).

\footnotetext{
${ }^{6}$ Proxy for Solar radiation
} 
The next part of the positive feedback cycle to be modelled is how this increase in the residential solar PV systems on the grid affects the residential electricity pricing. This is represented by the residential electricity price equation (3) in the simultaneous equations model. Residential electricity price is a function of the type of fuel used in the production of electricity (Coal Share), the previous time periods residential electricity price, the predicated residential solar PV uptake, the wholesale price of electricity (WPElec) and time dummy variables for the Month and Year. It is expected that increasing levels of solar PV uptake will increase residential electricity prices, due to an increasing number of customers' with solar PV systems demanding less electricity from the grid resulting in utilities charging more to remaining customers to meet its revenue requirements (ISO, 2016; Lijesen, 2007).

The final part of the positive feedback cycle to be modelled is how the resulting increasing penetration of residential solar PV and rising residential electricity prices will lead to a decrease in residential electricity demand. The residential electricity demand equation (4) is the last equation in the simultaneous equations model. The residential electricity demand $(E D)$ is a function of the predicated residential electricity price, the predicated residential solar PV uptake, the average monthly temperature and the average monthly income (Fan \& Hyndman, 2011; Holtedahl \& Joutz, 2004; Krishnamurthy \& Kristrom, 2015). A priori, higher predicated value for residential electricity price (PElec) will lead to a fall in residential electricity demand. A similar result is expected with an increasing residential solar PV uptake. The average monthly temperature (Temp) is expected to have a negative relationship with residential electricity demand, i.e. as the outside temperature starts to rise, the usage of clothes dryers and electric heating will decrease. The variable average monthly wage is included in the residential electricity demand equation. The relationship with demand could be either positive or negative, as a person's income (Inc) increases they may buy more home appliances and therefore demand more electricity. However, a higher income could allow a person to purchase higher energy efficient appliances, which would demand less electricity. Time dummies for the Month and Year are also included. Both Appendix B and C summarize the description of the variables used in the analysis, as well as the hypotheses on the sign of the coefficients for each equation.

Due to endogeneity, the residential electricity price equation is identified using instrumental variables of the percentage of coal used in electricity production (CoalShare) and the lagged electricity price $\left(\right.$ PElec $\left._{t-1}\right)$. Coal is often used as a fuel in baseload generation due to its lower price when compared to other fuels. An increase in the percentage of coal used in generation reduces electricity bills, which would lead to an increase in electricity demand. Coal 
Share in the monthly generation mix can only affect electricity demand through the price of electricity, which is only determined by a shift in electricity supply. We expect to find a strong positive relationship between electricity price and the monthly lagged electricity price since the residential rates are fairly stable over time (Eryilmaz \& Sergici, 2016). The model satisfies the order condition for identification, as the number of excluded exogenous variables from each equation $(2,3 \& 4)$ is at least as large as the number of right-hand side endogenous variables. The variables ${ }^{7}$ are expressed in $\log -\log (\ln )$, so that the results can easily be expressed in percentage changes that identify elasticities.

Simultaneous equation models may be biased if estimated with ordinary least method due to the inherent correlation among the error terms and the explanatory variables in the specified equations. In this study a three stage least square (3SLS) method (Eryilmaz \& Sergici, 2016; Jeon \& Moffett, 2010; Zellner \& Theil, 1962) is employed. The assumptions associated with the 3SLS approach are: the error term is not correlated with the exogenous variables in the model $\operatorname{Cov}(\varepsilon i, t, c \mid X i, t, c)=0$, where $X$ represents the exogenous variables on the right hand side of each of equation, $i$ represents the number of equations $(i=1,2,3)$, and $t$ stands for each time period, taking into account the cross equation correlation of error. The instrumental variables $\mathrm{Z}$ are correlated with the regressors' $\mathrm{E}\left[\mathrm{z}^{\prime} \mathrm{x}\right] \neq 0$, while $\mathrm{Z}$ is also uncorrelated with the error term $\varepsilon, E\left[z^{\prime} \varepsilon\right]=0$ and $Z$ is not a direct cause of the dependent variable $y, \operatorname{cov}[y, z \mid x]$ $=0$ (Wooldridge, 2010).

\subsection{Descriptive Statistics}

The three main variables of interest in our positive feedback cycle model are: residential solar PV uptake, residential electricity price and residential electricity demand. The following section highlights the associated descriptive statistics.

[Table 1 Here]

The average monthly residential solar PV installations over the period examined was 10,240. In terms of added electrical capacity to these three nations grids over the five-year

${ }^{7}$ PV, PElec, Sunlight, AvrCostPV, PElec ${ }_{\mathrm{t}-1}$, WPElec Temp, Inc. 
period examined, Australia was the highest in terms of installed residential solar PV capacity with 4,921 MW, followed by the UK at 2,425 MW and Ireland at 1.3 MW. The next variable of interest in the positive feedback cycle is residential electricity price. The average residential electricity price for the panel in 2010 was $0.17 € / \mathrm{kWh}$ by 2015 the average electricity price had increased to $0.20 € / \mathrm{kWh}$. A similar price trend is seen in the individual countries with an increase in residential electricity over the time period examined (Fig. 1.). The final variable of interest is the residential electricity demand, the demand for electricity decrease from an average of $5,730 \mathrm{GW} / \mathrm{h}$ in 2010 to $5,326 \mathrm{GW} / \mathrm{h}$ in 2015 . The yearly demand figure for electricity is lower in all three countries for 2015 when compared to 2010. After analysing the summary statistics of the three variables of major interest, we can infer the positive feedback cycle or loop in existence across all countries, a rising cumulative capacity in terms of residential solar PV systems over the period, while the residential electricity prices have increased from 2010 to 2015 and residential electricity demand has decreased over the same period.

[Figure 1 Here]

\section{Results and discussion}

Firstly, unit root tests are conducted to confirm whether the variables are stationary are not. The Im, Pesaran and Shin (2003) and Levin, Lin and Chu (2002) panel unit root tests were employed. The null hypothesis of the test is that each series in the panel dataset contains a unit root while alternatively, at least one of the individual series in the panel is stationary (no unit root). Hence, given the unit root results (Appendix D), we proceed by testing for the existence of cointegration. Table 2 presents the Pedroni cointegration statistics for the model, the null hypothesis of no cointegration is rejected therefore the pooled regression is estimated and the results are summarised in table 3.

[Table 2 Here]

The key results from the simultaneous equation model are as follows, firstly the solar uptake equation (2) show that a $1 \%$ increase residential electricity price will significantly increase residential solar PV uptake by $0.55 \%$. This result supports the theory of the positive 
feedback cycle, according to which, higher electricity prices lead to an increase in the installations of residential solar PV systems (see column 1 in Table 3 below).

Secondly, results (see column 2 in Table 3 below) from the residential electricity price equation (3) show that the other key variable in the positive feedback cycle, residential solar PV uptake, significantly affects the price of residential electricity with an increase of $0.41 \%$ in price given a $1 \%$ in solar PV uptake.

[Table 3 Here]

Finally, results from the residential electricity demand equation (4) show that the key variables, solar PV uptake and residential price of electricity, in the positive feedback cycle have a significant effect on residential electricity demand (see column 3 in Table 3 above). Results indicate that a $1 \%$ increase in the residential electricity price, will lead to a decrease in residential electricity demand by $3.55 \%$. While a $1 \%$ increase in residential solar PV uptake will decrease the amount of residential electricity demand by the residential sector by $1.45 \%$.

\section{Conclusion and Policy Implications}

Residential solar photovoltaic (PV) systems, as well as other forms of micro renewable energy systems (micro-RES), have the potential to significantly contribute towards a country's climate change goals; however, they could also be a disruptive innovation to the traditional electrical industry. Currently, the adopters of micro-RES still rely on the national electricity grid for when their system stops producing electricity due to the lack of ideal atmospheric conditions. However, with residential battery storage options for electricity always improving and reducing in price, micro-RES and the traditional electricity industry could be akin to mobile telephones and the fixed land lines industry.

The gaining popularity of solar PV systems in the residential electricity market is not only due to the falling cost of systems, but also could be attributed to the positive feedback cycle. This is where residential electricity customers reduce their net purchases from the electric grid by adopting solar PV systems; however, the costs incurred by the electrical utility companies do not decrease proportionally to the decrease in electricity consumed. This happens because the electrical utilities must pay for transmission and distribution infrastructure expenses and such fixed costs are recovered over decades. Electrical utilities will have to raise 
their price of electricity to make up for the loss and thus incentivise the remaining electricity customers to adopt solar PV systems.

This study extended this line of research by examining the residential electricity markets in three countries: the U.K., Ireland and Australia, to provide evidence of any positive feedback cycle. The empirical analysis used a simultaneous equation model to illustrate the interactions of residential solar PV uptake, residential electricity prices and demand, and to provide evidence of any positive feedback cycle in the market. To this end, a three stage least squares regression model was employed in relevance to the pooled panel data set of Australia, Ireland and the UK. The findings documented: a positive relationship between electricity prices and solar PV uptake, a positive relationship between solar PV uptake and electricity price, and finally, a negative relationship between electricity prices and electricity demand. Moreover, a negative relationship was found between solar PV and electricity demand. In other words, the findings indicated that a positive feedback cycle was in effect, as the adoption of residential solar PV systems was leading to a positive feedback cycle via increasing residential electricity prices and decreasing residential electricity demand.

The evidence of the positive feedback cycle in an electricity market could raise issues for electricity utilities, transmission system operators, and government energy departments, as some have suggested that it would result in a utility 'death spiral'. In our analysis, it seems that Australia and the UK would be more at risk due to the larger cumulative capacity of residential solar PV systems added to the grid in a short period of time. To tackle this issue, there needs to be a restructuring of current renewable energy policies for current and future adopters of micro-RES. If environmental goals are to be achieved, then stakeholders in the electricity market will have to support the adoption of solar PV in a sustainable way, while not punishing non-adopters with higher electricity rates.

Appendix A. Data sources

\begin{tabular}{cccc}
\hline Variable & Ireland & Britain & Australia \\
\hline Solar PV Uptake & ESB & GOV.UK & $\begin{array}{c}\text { Australian Photovoltaic } \\
\text { Institute }\end{array}$ \\
\hline Cost of Solar PV & The OpenPV Project by National Renewable Energy Laboratory \\
\hline $\begin{array}{c}\text { Residential } \\
\text { Electricity } \\
\text { Demand }\end{array}$ & $\begin{array}{c}\text { Central Statistics } \\
\text { Office }\end{array}$ & GOV.UK & Office of Chief Economist \\
\cline { 2 - 4 } & & &
\end{tabular}




\begin{tabular}{cccc}
\hline Coal Share & $\begin{array}{c}\text { Central Statistics } \\
\text { Office }\end{array}$ & GOV.UK & Office of Chief Economist \\
\hline $\begin{array}{c}\text { Wholesale Price of } \\
\text { Electricity }\end{array}$ & $\begin{array}{c}\text { Single Electricity } \\
\text { Market Operator }\end{array}$ & Thomson Reuters DataStream & $\begin{array}{c}\text { Australian Energy Market } \\
\text { Operator }\end{array}$ \\
\hline $\begin{array}{c}\text { Residential Price } \\
\text { of Electricity }\end{array}$ & Eurostat & Eurostat & $\begin{array}{c}\text { Australian Energy Market } \\
\text { Commission }\end{array}$ \\
\hline Income & Met Eireann & GOV.UK & $\begin{array}{c}\text { Australian Bureau of } \\
\text { Statistics }\end{array}$ \\
\hline Temperature & Met Eireann & GOV.UK & The Bureau of Meteorology \\
\hline $\begin{array}{c}\text { Sunlight Hours } \\
\text { Government }\end{array}$ & ESB & GOV.UK & The Bureau of Meteorology \\
\hline Support Scheme & & & australia.gov.au \\
\hline
\end{tabular}

Appendix B. Variables description.

\begin{tabular}{|c|c|c|c|}
\hline Variable & Notation & Description & Unit \\
\hline Solar PV Uptake & PV & Monthly solar PV average capacity installed & kw \\
\hline Cost of Solar PV & AvrCostPV & Monthly per watt cost of PV. & $€ / \mathrm{kw}$ \\
\hline $\begin{array}{l}\text { Residential } \\
\text { Electricity Demand }\end{array}$ & ED & Monthly electricity consumed by residential sector & $\mathrm{Gw} / \mathrm{h}$ \\
\hline Coal Share & CoalShare & Percentage of Coal used in Electricity Production & $\%$ \\
\hline $\begin{array}{l}\text { Wholesale } \\
\text { Electricity Price }\end{array}$ & WPElec & Monthly Wholesale Electricity Price & $€ / \mathrm{MWh}$ \\
\hline $\begin{array}{l}\text { Residential Price of } \\
\text { Electricity }\end{array}$ & PElec & $\begin{array}{c}\text { Price of residential electricity, Band DC : } 2,500 \mathrm{kWh}< \\
\text { Consumption }<5,000 \mathrm{kWh} \text {. All taxes and levies } \\
\text { included. }\end{array}$ & $€ \mathrm{kWh}$ \\
\hline Income & Inc & Average Monthly Income & $€$ \\
\hline Temperature & Temp & Monthly Average Temperature & ${ }^{\mathrm{O}} \mathrm{C}$ \\
\hline $\begin{array}{l}\text { Lagged Residential } \\
\text { Price of Electricity }\end{array}$ & LPElec & Lagged Price of residential electricity & $€ \mathrm{kWh}$ \\
\hline Sunlight Hours & Sunlight & $\begin{array}{c}\text { (Proxy for solar radiation) Average monthly duration } \\
\text { of Sunlight }\end{array}$ & Hours \\
\hline $\begin{array}{c}\text { Government } \\
\text { Support Scheme }\end{array}$ & Scheme & $\begin{array}{l}\text { Dummy Variable for months that a support scheme } \\
\text { (eg. Feed in Tariff) was operational }\end{array}$ & $\begin{array}{l}1=\text { scheme open } \\
0=\text { scheme closed }\end{array}$ \\
\hline
\end{tabular}

Appendix C. Investigated hypotheses

\begin{tabular}{|c|c|c|c|}
\hline $\begin{array}{l}\text { Estimated } \\
\text { Equation }\end{array}$ & Variable & $\begin{array}{l}\text { Expected } \\
\text { Sign }\end{array}$ & Hypothesis \\
\hline Equation 1 & $\begin{array}{l}\text { Residential Electricity } \\
\text { Price }\end{array}$ & + & Increase in electricity price increases solar PV uptake \\
\hline Solar Uptake & $\begin{array}{l}\text { Government Support } \\
\text { Scheme }\end{array}$ & + & $\begin{array}{l}\text { Months in which the government support schemes are in } \\
\text { operation should result in higher uptake }\end{array}$ \\
\hline
\end{tabular}




\begin{tabular}{|c|c|c|c|}
\hline \multirow{6}{*}{$\begin{array}{l}\text { Equation } 2 \\
\text { Residential } \\
\text { Electricity } \\
\text { Price }\end{array}$} & Sunlight Hours & + & $\begin{array}{l}\text { Countries with higher average sunlight hours should have } \\
\text { a higher solar PV uptake }\end{array}$ \\
\hline & Cost of Solar PV & - & Lower solar PV costs, increases solar PV uptake \\
\hline & Coal Share & - & Increase in coal generation, decreases electricity prices \\
\hline & Lagged Electricity Price & + & $\begin{array}{l}\text { Increase in previous months prices, increases price of } \\
\text { electricity }\end{array}$ \\
\hline & Solar PV Uptake & + & Increase in solar PV uptake, increases price of electricity \\
\hline & $\begin{array}{l}\text { Wholesale Price of } \\
\text { Electricity }\end{array}$ & + & $\begin{array}{l}\text { Increase in wholesale price of electricity, increases price } \\
\text { of electricity }\end{array}$ \\
\hline \multirow{4}{*}{$\begin{array}{l}\text { Equation } 3 \\
\text { Residential } \\
\text { Electricity } \\
\text { Demand }\end{array}$} & $\begin{array}{l}\text { Residential Electricity } \\
\text { Price }\end{array}$ & - & $\begin{array}{l}\text { Increase in electricity price, decreases the electricity } \\
\text { demanded }\end{array}$ \\
\hline & Solar PV Uptake & - & $\begin{array}{l}\text { Increase in solar PV uptake, decreases the electricity } \\
\text { demanded }\end{array}$ \\
\hline & Temperature & - & Higher Temperatures decreases electricity demanded \\
\hline & Income & $+/-$ & $\begin{array}{l}\text { A higher wage could have either a positive or negative } \\
\text { effect on Electricity demand. }\end{array}$ \\
\hline
\end{tabular}

\section{Appendix D. Panel Unit Root Tests}

\begin{tabular}{llcll}
\hline Variable & Method & Statistic & P-Value & Conclusion \\
\hline PElec & IPS & -5.79 & 0 & Stationary \\
& LLC & -7.339 & 0 & Stationary \\
Sunlight & IPS & -3.667 & 0 & Stationary \\
& LLC & -5.742 & 0.0002 & Stationary \\
WPElec & IPS & -8.676 & 0 & Stationary \\
& LLC & -10.098 & 0 & Stationary \\
ED & IPS & -4.408 & 0 & Stationary \\
& LLC & -6.51 & 0 & Stationary \\
CoalShare & IPS & -1.568 & 0.058 & Non-Stationary \\
& LLC & -4.023 & 0.0239 & Non-Stationary \\
Temp & IPS & -2.343 & 0.01 & Stationary \\
& LLC & -4.728 & 0.0046 & Stationary \\
PV & IPS & -12.546 & 0 & Stationary \\
& LLC & -0.9189 & 0 & Stationary \\
Inc & IPS & -3.021 & 0.001 & Stationary \\
& LLC & -5.227 & 0.0008 & Stationary \\
\hline
\end{tabular}




\section{Acknowledgements}

Chesser acknowledges a Fiosraigh Doctoral Scholarship from Dublin Institute of Technology.

\section{References}

Allen, S. R., Hammond, G. P., \& McManus, M. C. (2008). Prospects for and barriers to domestic micro-generation: A United Kingdom perspective. Applied Energy, 85(6), 528-544.

Arthur, W. B. (1990). POSITIVE FEEDBACKS IN THE ECONOMY. Scientific American, 262(2), 92-\&.

Balcombe, P., Rigby, D., \& Azapagica, A. (2013). Motivations and barriers associated with adopting microgeneration energy technologies in the UK. Renewable \& Sustainable Energy Reviews, 22, 655-666.

Ballester, C., \& Furio, D. (2015). Effects of renewables on the stylized facts of electricity prices. Renewable \& Sustainable Energy Reviews, 52, 1596-1609.

Balta-Ozkan, N., Yildirim, J., \& Connor, P. M. (2015). Regional distribution of photovoltaic deployment in the UK and its determinants: A spatial econometric approach. Energy Economics, 51, 417-429.

Cai, D. W. H., Adlakha, S., Low, S. H., De Martini, P., \& Chandy, K. M. (2013). Impact of residential PV adoption on Retail Electricity Rates. Energy Policy, 62, 830-843.

CER. (2016). Eligible systems. Retrieved from http://www.cleanenergyregulator.gov.au/RET/Howto-participate-in-the-Renewable-Energy-Target/Choosing-a-system/Eligible-systems

Chapman, A. J., McLellan, B., \& Tezuka, T. (2016). Residential solar PV policy: An analysis of impacts, successes and failures in the Australian case. Renewable Energy, 86, 1265-1279.

Chew, M., Heling, M., Kerrigan, C., Jin, D., Tinker, A., Kolb, M., . . Huang, L. (2012). Modelling Distributed Generation Adoption Using Electric Rate Feedback Loops. Paper presented at the $31^{\text {st }}$ USAEE/IAEE North American Conference Austin, Texas.

Costello, K. W., \& Hemphill, R. C. (2014). Electric utilities' death spiral': hyperbole or reality? The Electricity Journal, 27(10), 7-26.

Darghouth, N. R., Barbose, G., \& Wiser, R. (2011). The impact of rate design and net metering on the bill savings from distributed PV for residential customers in California. Energy Policy, 39(9), 5243-5253.

ElectricIreland. (2014). Electric Ireland Micro-Generation Pilot Scheme. Retrieved from https://www.electricireland.ie/residential/help/micro-generation/electric-ireland-microgeneration-pilot-scheme

Eryilmaz, D., \& Sergici, S. (2016). Integration of residential PV and its implications for current and futureresidential electricity demand in the United States. The Electricity Journal, 29, 41-52.

Fan, S., \& Hyndman, R. J. (2011). The price elasticity of electricity demand in South Australia. Energy Policy, 39(6), 3709-3719.

Felder, F. A., \& Athawale, R. (2014). The life and death of the utility death spiral. . The Electricity Journal, 27(6), 9-16.

Filippini, M. (2011). Short- and long-run time-of-use price elasticities in Swiss residential electricity demand. Energy Policy, 39(10), 5811-5817.

Gelabert, L., Labandeira, X., \& Linares, P. (2011). An ex-post analysis of the effect of renewables and cogeneration on Spanish electricity prices. Energy Economics, 33, S59-S65.

Holtedahl, P., \& Joutz, F. L. (2004). Residential electricity demand in Taiwan. Energy Economics, 26(2), 201-224. 
Im, K. S., Pesaran, M. H., \& Shin, Y. (2003). Testing for unit roots in heterogeneous panels. Journal of Econometrics, 115(1), 53-74.

ISO, C. (2016). Flexible Resources Help Renewables - Fast Facts. Retrieved from http://www.caiso.com/FASTSearch2/Pages/Results.aspx?sq=1\&k=Duck\%20Chart

Jeon, J. Q., \& Moffett, C. M. (2010). Herding by foreign investors and emerging market equity returns: Evidence from Korea. International Review of Economics \& Finance, 19(4), 698710.

Kaufmann, R. K., \& Vaid, D. (2016). Lower Electricity Prices and Greenhouse Gas Emissions due to Rooftop Solar: Empirical Results for Massachusetts. Energy Policy, 93, 345-352.

Krishnamurthy, C. K. B., \& Kristrom, B. (2015). A cross-country analysis of residential electricity demand in 11 OECD-countries. Resource and Energy Economics, 39, 68-88.

Laws, N. D., Epps, B. P., Peterson, S. O., Laser, M. S., \& Wanjiru, G. K. (2017). On the utility death spiral and the impact of utility rate structures on the adoption of residential solar photovoltaics and energy storage. Applied Energy, 185, 627-641.

Levin, A., Lin, C. F., \& Chu, C. S. J. (2002). Unit root tests in panel data: asymptotic and finitesample properties. . Journal of econometrics, 108(1), 1-24.

Li, Z., Boyle, F., \& Reynolds, A. (2011). Domestic application of solar PV systems in Ireland: The reality of their economic viability. Energy, 36(10), 5865-5876. doi:10.1016/j.energy.2011.08.036

Lijesen, M. G. (2007). The real-time price elasticity of electricity. Energy Economics, 29(2), 249-258.

McLaren, J., Davidson, C., Miller, J., \& Bird, L. (2015). Impact of rate design alternatives on residential solar customer bills: increased fixed charges, minimum bills and demand-based rates. The Electricity Journal, 28(8), 43-58.

Mills, A., Wiser, R., Barbose, G., \& Golove, W. (2008). The impact of retail rate structures on the economics of commercial photovoltaic systems in California. Energy Policy, 36(9), 32663277.

Nelson, T., Simshauser, P., \& Kelley, S. (2011). Australian residential solar Feed-in Tariffs: industry stimulus or regressive form of taxation? Economic Analysis and Policy, 41(2), 113-129.

Nelson, T., Simshauser, P., \& Nelson, J. (2012). Queensland solar feed-in tariffs and the merit-order effect: Economic benefit, or regressive taxation and wealth transfers? . Economic Analysis and Policy, 42(3).

Nicholson, E., Rogers, J., \& Porter, K. (2010). The relationship between wind generation and balancing-energy market prices in ERCOT: 2007-2009. . Contract, 303, 275-3000.

Payne, J. E. (2010). A survey of the electricity consumption-growth literature. Applied Energy, 87(3), 723-731.

Rodrigues, S., Torabikalaki, R., Faria, F., Cafofo, N., Chen, X. J., Ivaki, A. R., . . Morgado-Dias, F. (2016). Economic feasibility analysis of small scale PV systems in different countries. Solar Energy, 131, 81-95.

Ruth, M., \& Hannon, B. (2012). Positive Feedback in the Economy. In Modeling Dynamic Economic Systems Springer US.

Sahu, B. K. (2015). A study on global solar PV energy developments and policies with special focus on the top ten solar PV power producing countries. Renewable \& Sustainable Energy Reviews, 43, 621-634.

Salim, R. A., Hassan, K., \& Shafiei, S. (2014). Renewable and non-renewable energy consumption and economic activities: Further evidence from OECD countries. Energy Economics, 44, 350360.

Severance, C. A. (2011). A practical, affordable (and least business risk) plan to achieve " $80 \%$ clean electricity" by 2035. . The Electricity Journal., 24(6), 8-26.

Shafiei, S., \& Salim, R. A. (2014). Non-renewable and renewable energy consumption and CO2 emissions in OECD countries: A comparative analysis. Energy Policy, 66, 547-556.

Wooldridge, J. M. (2010). Econometric Analysis of Cross Section and Panel Data (2nd ed.): MIT Press.

Zahedi, A. (2010). A review on feed-in tariff in Australia, what it is now and what it should be. Renewable \& Sustainable Energy Reviews, 14(9), 3252-3255. 
Zellner, A., \& Theil, H. (1962). Three-stage least squares: simultaneous estimation of simultaneous equations. Econometrica Journal of the Econometric Society, 54-78.

Zhang, Y., Song, J. H., \& Hamori, S. (2011). Impact of subsidy policies on diffusion of photovoltaic power generation. Energy Policy, 39(4), 1958-1964. 